\title{
Fibroelastic Components of the Vesicourethral Junction of Rats in the Aging Process
}

\author{
Componentes Fibroelásticos de la Unión Vesicouretral de Ratas en el Proceso de Envejecimiento
}

\author{
"Gisele Reisdoerferer; ${ }^{* *}$ Kleber Fernando Pereira \& ${ }^{* * *}$ Renato Paulo Chopard
}

REISDOERFER, G; PEREIRA, K. F. \& CHOPARD, R. P. Fibroelastic components of the vesicourethral junction of rats in the aging process. Int. J. Morphol., 29(1):214-220, 2011.

SUMMARY: The vesicourethral junction comprising the vesical trigone, is relevant in setting and positioning of the urinary bladder, along with the vesical neck, fixed by lateral ligaments of the bladder and tendinous arch of the pelvis fascia. Namely, the puboprostatic ligament (men) and the pubovesical (women). The circular set elastic fibers in this junction are important and valuable in the elasticity and plasticity of the area, allowing quick expansion and withdrawal with the flow of urine, and associated to smooth muscle tissue and nerve control form an important collective to maintain urinary continence. The objective of the present study is to describe the elastic system in the vesicouretral junction in relation to aging and its involvement in the states of urinary continence and incontinence, as well as the study of the vesicouretral junction in various age groups while evaluating with electron transmission microscopy. To carry out the study, 12 Wistar rats were used, divided into groups: neonate (4 animals), adult group ( 4 animals) and aged group ( 4 animals). Electron transmission microscopy with use of tanic acid technique associated to glutaraldehyde fixation, satisfactorily showed the extreme structural differences between mature elaunin and oxytalan fibers present between intercelular spaces and bundles of collagen fibers. The phases of elastogenesis in neonate animals and degradation of the elastic system of older animals were also evaluated.

KEY WORDS: Collagen staple fibres; Elastic staple fibres; Vesico-urethral junction.

\section{INTRODUCTION}

The vesicourethral junction (VUJ) is the transition region from the bladder to the urethra, located in the bladder neck and is marked by the internal ostium of the urethra. The vesical neck, the lower and fixed part of the bladder, has a muscle with different behavior, since the muscle layers in this region are arranged round the inner ostium of the urethra, constituting the internal urethral sphincter (Woodburne, 1961).

Among the structural elements of the vesicourethral junction are the smooth muscle fibers, collagen and elastic fibers. Dass et al. (1999) worked with computerized images, quantified the elastic fibers in sections taken from the base of the bladder, VUJ and urethra of guinea pigs (male and female) and observed a significant increase in elastic fibers circularly arranged at the VUJ in relation to the other two regions examined. The authors reported that this particular arrangement of elastic fibers may be partly responsible for the elasticity and plasticity of VUJ, allowing its rapid expansion and retreat with the urine flow during bladder emptying. They also mentioned that the elastic fibers in the VUJ may be partly responsible for the passive and occlusive force in this region.

For some researchers, the fibroelastic tissue is the main factor in the generation of urethral and VUJ closure pressure at rest, where Awad \& Downie (1976), after eliminating the neural factors responsible for the intraurethral pressure, observed a residual pressure. This finding was confirmed by Bump et al. (1988), who demonstrated that the fibroelastic elements had an effect on the urethral pressure with profile equivalent to that shown by the vascular layer.

This study aims to describe the elastic system in the vesicourethral junction during the aging process and its role in the states of urinary continence / incontinence by typing the ultrastructure of elastic fibers by means of transmission electron microscopy.

\footnotetext{
* MSc in Morphofunctional Sciences - University of São Paulo, São Paulo, Brazil

** Professor at the Biological Sciences Course - UFG - Campus of Jataí - GO, Brazil

**** Professor of Anatomy - Institute of Biomedical Sciences, University of São Paulo, São Paulo, Brazil.
} 


\section{MATERIAL AND METHOD}

Material. The experiment included 12 male Wistar rats (Rattus norvegicus) obtained from the Central Animal Facility of the Biomedical Sciences Institute, University of São Paulo, maintained under controlled temperature $\left(21^{\circ} \mathrm{C}\right)$ and lighting (12 hours light/12 hours dark), with a balanced diet and water ad libitum, without nutritional constraints, which criteria followed the Ethics Research Committee and Laws in force (Law 1.153/95). The animals were divided into three groups distinguished by different age groups, of four animals each:

Neonate Group (21 days), Adult Group (200 days), Elder Group (450 days).

Methods. For analysis under transmission electron microscope, the animals were anesthetized by intraperitoneal injection with the use of anesthetic cocktail (40\% distilled water $+25 \%$ ketamine $+25 \%$ xylazine $+10 \%$ acepromazine) in which the heart beats were kept until perfusion. Through laparotomy, the dissection of the structures began until visualization of the urinary bladder, ureters and proximal urethra. The urinary bladder block, intravesical ureters and proximal urethra were removed, which was dissected to obtain the VUJ, also containing the internal ostium of the urethra and ureter ostia with the aid of a stereomicroscope, and fixed in $25 \%$ glutaraldehyde. After laparotomy and attainment of pieces, the segments containing the vesicourethral junction were reduced using a razor blade and fixed for 3 hours at $4^{\circ} \mathrm{C}$ in $2.5 \%$ glutaraldehyde solution and $0.25 \%$ tannic acid in $0.1 \mathrm{M}$ phosphate buffer ( $\mathrm{pH} 7.4$ ).

The samples were carefully washed with $0.1 \mathrm{M}$ phosphate buffer $(\mathrm{pH} 7.4)$ and post-fixed in $2 \%$ osmium tetroxide for 2 hours at $4^{\circ} \mathrm{C}$. The pieces were washed in saline solution and placed in $0.5 \%$ uranyl solution for 12 hours at room temperature. After this period, the material was washed once again in saline solution and the following started: dehydration process in increasing series of alcohol $-70^{\circ}$, $80^{\circ}, 95^{\circ}$ - bath of 15 minutes each -4 baths of 15 minutes each, and two baths of $99 \%$ propylene oxide for 15 minutes each. After passage in propylene oxide, the samples were placed in a mixture of resin and propylene oxide in a 1:1 ratio. The infiltration was done by shaking the material in rotation $(1 / 2 \mathrm{rpm})$, in support with $45^{\circ}$ of angle in relation to the ground, attached to an electric motor shaft for 4 hours.
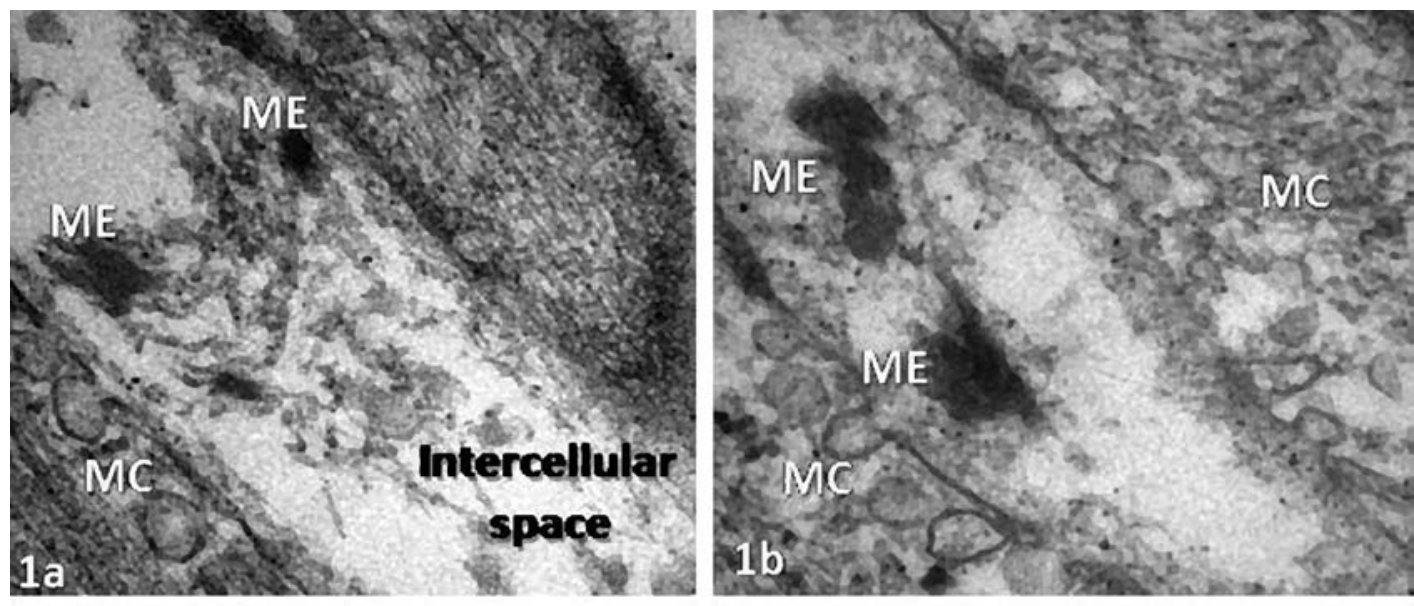

Fig. 1. a - VUJ electron micrograph of neonate Wistar rats (21 days). Note mature elastic fibers (ME) and muscle cell (MC). (100K). b - VUJ electron micrograph of adult Wistar rats (200 days). Note mature elastic fibers (ME) and muscle cells (MC). (100K). c - VUJ electron micrograph of elder Wistar rats (450 days). Note mature elastic fibers (ME) and collagen fibers $(\mathrm{CF})$. (50K). 
After this period, this mixture was replaced by pure resin and the material was placed once again in rotation for over 12 hours. Again, the resin was replaced with pure resin, remaining in oven at $37^{\circ} \mathrm{C}$ for 1 hour; then the pieces were included in Spurr resin, maintaining the oven at $60^{\circ} \mathrm{C}$ for 5 days.

Semi-thin sections of 400nm were obtained in ultramicrotome, stained with with toluidine blue to locate the structures under study. Once located, ultra-thin sections were made on ultra-microtome collected with a 200 mesh screen and contrasted with uranyl acetate and lead citrate. The samples were then photographed using a transmission electron microscope for analysis of differences of ultrastructural components of oxytalan, elauninic and mature elastic fibers between neonate, adult and elder groups.

\section{RESULTS}

The elastic system in VUJ revealed fibers longitudinally, obliquely and circularly oriented, forming a tangle between the intercellular spaces of the muscle layer and also between the bundles of collagen fibers. The results also showed that for all age groups, the three types of fibers of the elastic system were found, which are satisfactorily typified according to the amount of amorphous and/or microtubular components.

Figures $1 \mathrm{a}, 1 \mathrm{~b}$ and $1 \mathrm{c}$ showed mature elastic fibers composed of electro-dense, compact and abundant amorphous material (elastin) for neonate, adult and elder groups respectively. The elaunin fibers were typified in three age groups, with scarce amorphous material (elastin) and microtubular material in larger quantities, as illustrated in Figures 2a (neonate group), 2b (adult group) and 2c (elder group), as well as oxitalanic fibers are identified in neonates (figure 3a) and adults (Fig. 3b), with a microtubular component forming bundles arranged in parallel not associated with elastin.

It was found that in the neonate group, the elastic system in addition to being well-characterized, elastogenesis steps occurred, where there was a transition from oxytalan to elauninic fibers, as shown in Figure $4 \mathrm{a}$, and elaunin fibers evolving into mature fibers, in Figure $4 b$. Figure $4 c$ shows that in the elder group, the mature elastic fibers are degraded and with irregular contours.
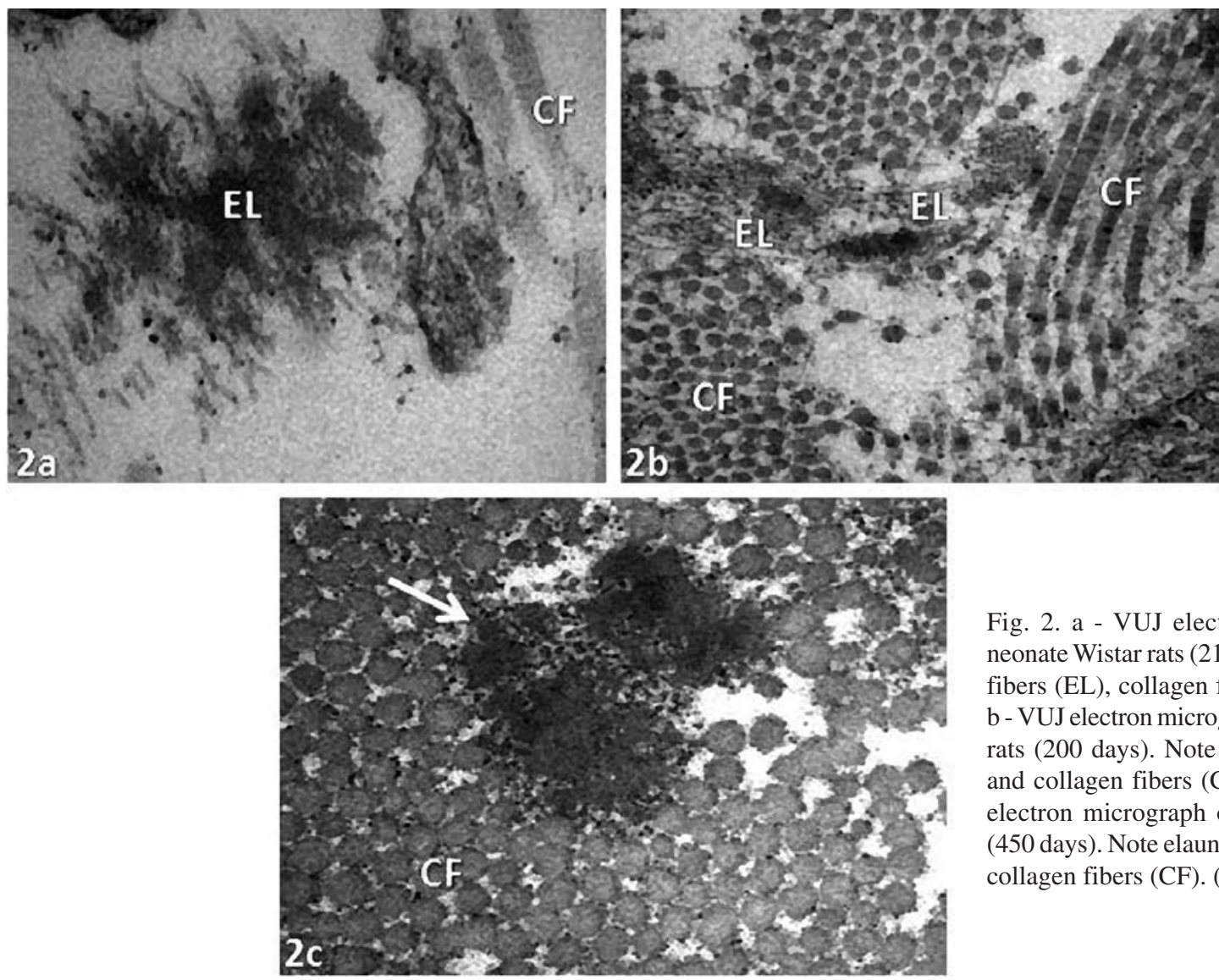

Fig. 2. a - VUJ electron micrograph of neonate Wistar rats (21 days). Note elaunin fibers (EL), collagen fibers (CF). (100K). b - VUJ electron micrograph of adult Wistar rats (200 days). Note elaunin fibers (EL) and collagen fibers (CF). (50K). c - VUJ electron micrograph of elder Wistar rats (450 days). Note elaunin fibers (arrow) and collagen fibers $(\mathrm{CF}) .(75 \mathrm{~K})$ 

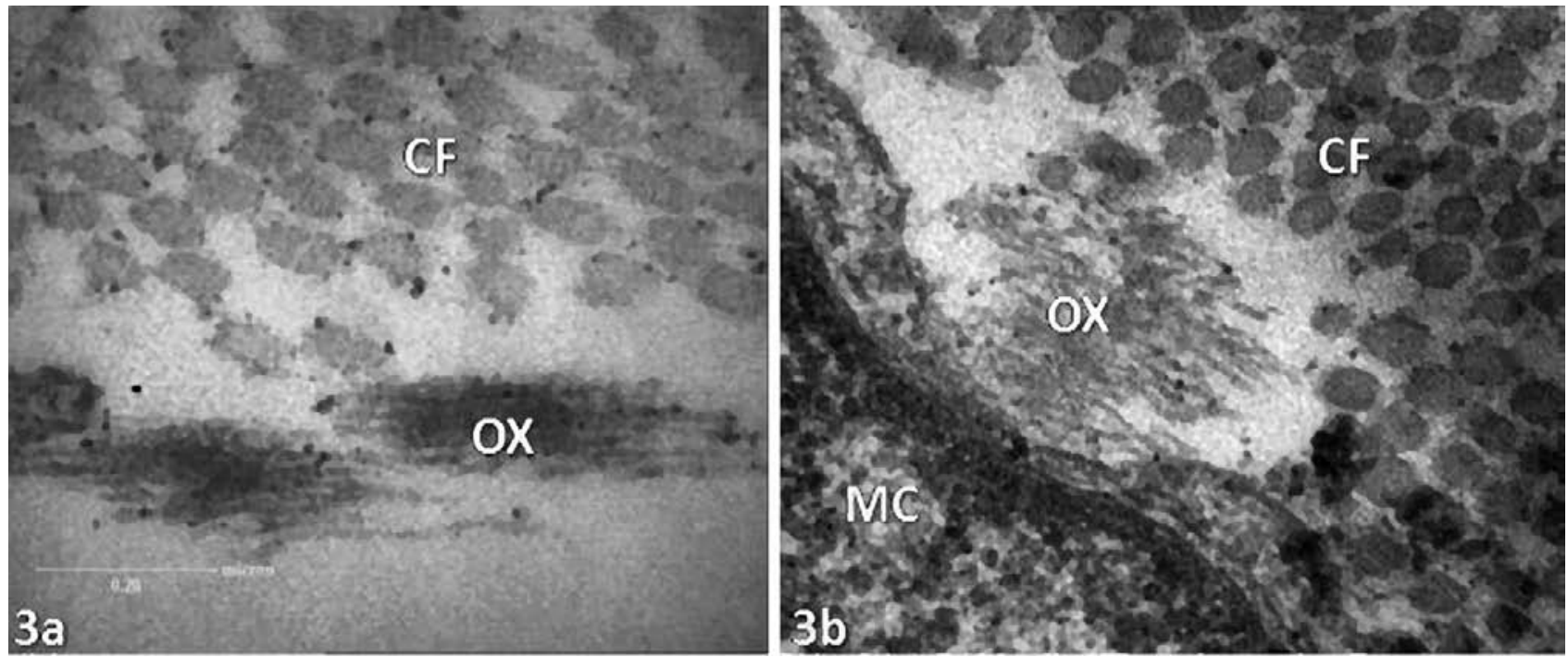

Fig. 3. a - VUJ electron micrograph of neonate Wistar rats (21 days). Note oxytalan fibers (OX), and collagen fibers (CF) (43.120X). b VUJ electron micrograph of adult Wistar rats (200 days). Note oxytalan fibers (OX), collagen fibers (CF) and muscle cells (MC) (100K).
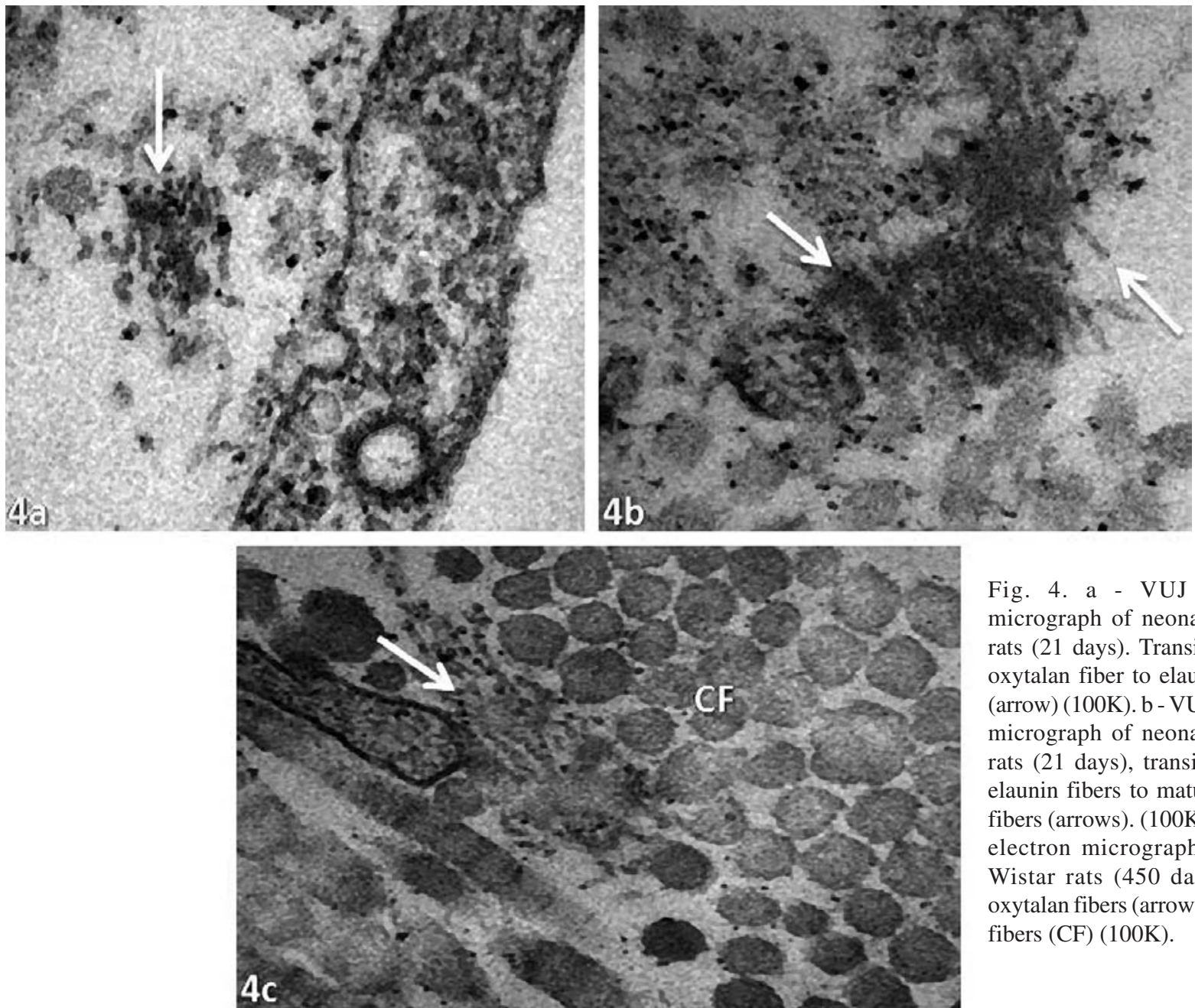

Fig. 4. a - VUJ electron micrograph of neonate Wistar rats (21 days). Transition from oxytalan fiber to elaunin fibers (arrow) (100K). b - VUJ electron micrograph of neonate Wistar rats (21 days), transition from elaunin fibers to mature elastic fibers (arrows). (100K). c - VUJ electron micrograph of elder Wistar rats (450 days). Note oxytalan fibers (arrow), collagen fibers $(\mathrm{CF})(100 \mathrm{~K})$. 


\section{DISCUSSION}

The ultrastructural typifying of fibers from the elastic system by transmission electron microscopy and use of the tannic acid technique was studied by some authors, and they have reported that the use of tannic acid marks the amorphous component of elastic fibers intensely (Kajikawa et al., 1975) and a uniform and reliable view of the elastic fibers is achieved if the fixing component (glutaraldehyde) contains tannic acid, with an increase in the electronic density of elastin and microfibrils (Cotta-Pereira et al., 1976).

Our findings are in line with the authors that there is a better marking of elastin and microfibrils present in the ultrastructural composition of elastic system fibers using tannic acid associated with glutaraldehyde fixation, where every type of elastic fiber could be evidenced in relation to differences they present as for their ultra-structure, where the mature elastic fibers showed a highly electro-dense, compact and abundant amorphous material composed of elastin only. This concurs with the findings of Kajikawa et al.; Cotta-Pereira et al. (1976) and Sawada et al. (2006), the elaunin fibers, in turn, are ultrastructurally characterized by being composed of scarce amorphous material scattered amid the microtubular component, as previously shown by CottaPereira et al. $(1976,1977)$. However, the oxytalan fibers are represented by bundles of microtubules arranged in parallel, confirming the findings of Simmons \& Avery (1980), De Carvalho \& Line (1996), Chopard et al. (1998) and Chopard \& Gerhard (2000).

It was also noted that the elastic fibers of VUJ are in the intercellular spaces of the muscle layer and between the bundles of collagen fibers, thus presenting the same location of the elastic fibers of the vas deferens as previously reported by Paniagua et al. (1983) in electro-microscopic study of this structure.

Some authors state that the arrangement of elastic system fibers in the tissue are reflected in the functions they were due to play: support, elasticity, resilience, compliance, expansion or elastic retreat (De Carvalho \& Line; CottaPereira et al., 1977; Kielty et al., 2002; Ross \& Bornstein, 1969; Ushiki \& Murakumo, 1991; Ushiki, 2002). In our study, the three types of elastic fibers in VUJ were observed, being dispersed throughout the muscle, thus associating this finding with its function and especially the internal ostium of the urethra, of elasticity, plasticity, expansion and quick retreat of urine flow. It was then evidenced that the elastic system of VUJ is present throughout the muscular layer and in different directions to perform elasticity, supply pressure for closing the site at rest, apaarticularly elastic retreat, with no deformation of the structure after passage of urine. Thus complementing the muscular action and giving support, acting on the VUJ not only one, but with various functions. This confirms the findings of Awad \& Downie, Bump, Dass et al., Gosling et al. (1979) and Woodburne making the VUJ a tissue with dynamic flexibility and reversible extensibility.

It is also known that each type of elastic fiber plays a role, which is determined by the amount of elastin and microtubules, where elastin is responsible for elasticity and elastic retreat (Ross \& \& Bornstein; Ross, 1973). Microtubules provide for compliance during smooth muscle contraction, anchoring and flexibility of structural rearrangement, preventing an overstretching of the tissue (De Carvalho \& Line). Thus, it is suggested that the oxytalan fibers in VUJ are present because this region is subject to constant tension, reinforcing this classical definition of functions of the microtubules in the tissue, as reported by the authors.

Moreover, the mature elastic fibers (elastin), become responsible for elasticity and elastic retreat of the VUJ, and in turn, elaunin fibers assume the intermediary role between oxytalan and mature fibers, providing functional adaptation to VUJ, as previously described by Cotta-Pereira et al. (1977, 1984) studying the skin, so the function of an elastic fiber complements the action of another and form in VUJ, a microfibril-elastin system, as already described by Ushiki, working as a distributor of uniform tension forces in the tissue, maintaining tissue resilience and adapting the site for urine flow.

De Carvalho \& Line reported some changes of the elastic system in relation to tissue aging and Sephel \& Davidson (1986) and Uitto et al. (1989) stated that the advancing age leads to a decline in the elastin biosynthesis rates. These findings that agree with our study, where degraded mature elastic fibers with irregular contours were observed in older animals, which leads us to suspect that these animals show a decrease in quality of the function that elastin plays in VUJ, which is considered a natural aging process. The decrease in muscle tone will lead to a more permeable physiological sphincter, favoring gradual processes of urinary incontinence. The fact that the local elastic system is not responsible for this pathological condition, since studies have shown that urinary incontinence occurs due to urodynamic problems such as deficiency or absence of detrusor activity must also be taken into account. Urethral pressure on active or incompetent, leading to undesirable intra-vesical pressure changes (Feneley et al., 
1982). Systemic and psychological diseases and use of certain drugs (Resnick \& Yalla, 1985), as well as the sphincteric action and pressure maintenance depend not only on the VUJ morphology, but also on the urethral wall, which works associated with the pelvic diaphragm, supporting the bladder neck directly or indirectly.

We believe that in the VUJ, the distribution of elastic fibers is homogeneous and there is a myoelastic system formed by the elastic system with muscle and collagen fibers, where the transmission electron microscopy results qualitatively revealed an increase in the collagen content in older animals. Thus, if we transfer the findings in animals to man, we can hypothetically assume that the elastic system in VUJ serves as a compensatory support of the trigone muscular layer by presenting more functional changes in the aging process and also by being a target for disease and surgery. Therefore, the elastic system in the VUJ is indirectly responsible for the maintenance of the urinary continence regardless of age group that the specimen belongs to.

\section{CONCLUSIONS}

The ultrastructural differences of elastic fibers in VUJ can be distinguished using the tannic acid technique associated with glutaraldehyde in the preparation of pieces for transmission electron microscopy, in which the mature elastic fibers have an electro-dense, compact and amorphous component. The elauninic fibers have microtubular component more abundant than the amorphous component and the oxitalanic fibers being formed exclusively bymicrotubules.

The findings of this research lead us to infer that the elastic system of VUJ is not a component that determines the onset of urinary incontinence in the physiological aging process, but is indirectly responsible for the urinary continence in all age groups, emphasizing that in the older animal, the elastic fibers act as support of the local smooth muscle, which presents more relevant changes with advancing age than the elastic system itself.

REISDOERFER, G; PEREIRA, K. F. \& CHOPARD, R. P. Componentes fibroelásticos de la unión vesicouretral de ratas en el proceso de envejecimiento. Int. J. Morphol., 29(1):214-220, 2011.

RESUMEN: La unión vesico-uretral, componente del trígono vesical, posee una relevante importancia en la fijación y posicionamiento de la vejiga urinaria conjuntamente con el cuello vesical, fijado por los ligamentos laterales de la vejiga y arco tendinoso de la fascia de la pelvis. Principalmente, sus componentes anteriores son: el ligamento puboprostático en los hombres y el ligamento pubovesical en las mujeres. Las fibras elásticas dispuestas circularmente en esta unión, son de valiosa importancia en la elasticidad y plasticidad de la región, permitiendo expansión y retiro rápido con el flujo de la orina, y asociado a musculatura lisa y control nervioso forman un conjunto importante para el mantenimiento de la continencia urinaria. Debido a existencia de puntos no esclarecidos en esta región en relación al sistema elástico y su participación en los estados de continencia/incontinencia urinaria, el presente trabajo tiene por objetivo el estudio de la unión vesico-uretral evaluándola en diferentes grupos etarios, a través de la microscopía electrónica de transmisión. Fueron utilizados 12 ratones Wistar, divididos en grupo de neonatos (4 animales), grupo adulto (4 animales) y grupo de ratones viejos (4 animales). La microscopía electrónica de transmisión, con uso de la técnica del ácido tánico asociado al fijador glutaraldeído, mostró satisfactoriamente las diferencias ultraestructurales entre las fibras elásticas maduras, elaunínicas y oxitalánicas, presentes entre los espacios intercelulares de las células musculares y haces de fibras colágenas, y también fases de elastogénesis en animales neonatos y envejecimiento y degradación del sistema elástico en los animales mayores.

PALABRAS CLAVE: Fibras colágenas; Fibras elásticas; Unión vesico-uretral.

\section{REFERENCES}

Awad, S. A. \& Downie, J. W. Relative contributions of smooth and striated muscles to the canine urethral pressure profile. Br. J. Urol., 48:347-54, 1976.

Bump, R. C. Dynamic urethral pressure profilometry pressure transmission ratio determinations after continence surgery: understanding the mechanism of success, failure, and complications. Obstet. Gynecol., 72:870-4, 1988 .
De Carvalho, H. F. \& Line, S. R. Basement membrane associated changes in the rat ventral prostate following castration. Cell Biol. Int., 20:809-19, 1996.

Chopard, R. P.; Lucas, G. A.; Gerhard, R. \& Lourenço, M. G. Histomorphological study in age related changes in the elastic fiber system of the basilar artery. Ital. J. Anat. Embryol., 103:157-75, 1998. 
Chopard, R. P. \& Gerhard, R. Histomorphometrical study of the elastic fiber system in the anterior cerebral artery of man. Arq. Neuropsiquiatr., 58:1040-6, 2000.

Cotta-Pereira, G.; Rodrigo, F. G. \& David-Ferreira, J. F. The use of tannic acid-glutaraldehide in the study of elastic and elastic-related fibers. Stain Technol., 51:7-11, 1976.

Cotta-Pereira, G.; Rodrigo, F. G. \& David-Ferreira, J. F. The elastic system fibers. Adv. Exp. Med. Biol., 79:19-30, 1977.

Cotta-Pereira, G.; Del-Claro, L. M. \& Montes, G. S. Distribution of elastic system fibers in hyaline and fibrous cartilages of the rat. Acta Anat., 119:80-5, 1984.

Dass, N.; McMurray, G. \& Brading, A. F. Elastic fibres in the vesicourethral junction and urethra of the guinea pig: quantification with computerised image analysis. $J$. Anat., 195:447-53, 1999.

Feneley, R. C.; Thomas, D. G. \& Blannin, J. P. Urinary incontinence. J. R. Coll. Physicians Lond., 16:89-93, 1982.

Gosling, J. The structure of the bladder and urethra in relation to function. Urol. Clin. North Am., 6:31-8, 1979.

Kajikawa, K.; Yamaguchi, T.; Katsuda, S. \& Miwa, A. An improved electron stain for elastic fibers using tannic acid. J. Electron Microsc., 24:287-9, 1975.

Kielty, C. M.; Sherratt, M. J. \& Shuttleworth, C. A. Elastic fibers. J. Cell Sci., 115:817-28, 2002.

Paniagua, R.; Regadera, J.; Nistal, M. \& Santamaría, L. Elastic fibres of the human ductus deferens. J. Anat., 137:467-76, 1983.

Resnick, N. M. \& Yalla, S. V. Management of urinary incontinence in the elderly. N. Engl. J. Med., 313:800-5, 1985.

Ross, R. \& Bornstein, P. The elastic fiber. I. The separation and partial characterization of its macromolecular components. J. Cell Biol., 40:366-81, 1969.

Ross, R. The elastic fiber. J. Histochem. Cytochem., 21:199208, 1973.

Sawada, T.; Sugawara, Y.; Asai, T.; Aida, N.; Yanagisawa, T.; Ohta, K. \& Inoue, S. Immunohistochemical characterization of elastic system fibers in rat molar periodontal ligament. J. Histochem. Cytochem., 54:1095103, 2006.

Sephel, G. C. \& Davidson, J. M. Elastin production in human skin fibroblast culture and its decline with age. J. Invest. Dermatol., 86:279-85, 1986.

Simmons, T. A. \& Avery, J. K. Electron dense staining affinities of mouse oxytalan and elastic fibers. J. Oral Pathol., 9:183-8, 1980.

Uitto, J.; Fazio, M. J. \& Olsen, D. R. Molecular mechanisms of cutaneous aging: age-associated connective tissue alterations in the dermis. J. Am. Acad. Dermatol., 21:61422, 1989.

Ushiki, T. \& Murakumo, M. Scanning electron microscopic studies of tissue elastin components exposed by a KOIICollagenase or simple $\mathrm{KOH}$ digestion method. Arch. Histol. Cytol., 54:427-436, 1991.

Ushiki, T. Collagen fibers, reticular fibers and elastic fibers: A comprehensive understanding from a morphological viewpoint. Arch. Histol. Cytol., 65:109-26, 2002.

Woodburne, R. T. The sphincter mechanism of the urinary bladder and the urethra. Anat. Rec., 141:11-20, 1961.

\section{Correspondence to: \\ Reisdoerfer, G. \\ Caixa Postal 94 \\ CEP 85530-000 \\ Clevelândia - PR \\ BRAZIL}

Email: greisdoerfer@usp.br

Received: 30-07-2010

Accepted: 26-11-2010 